\section{Sequências de Formação no Ensino} de Língua Estrangeira: Instrumentos Mediadores para Desenvolvimento de Saberes Docentes

Formation Sequences in Foreign Language Teaching: Mediating Instruments for the Development of Teacher Knowledge

Marileuza Ascencio Miquelante*, Vera Lucia Lopes Cristovão*

RESUMO: A formação inicial de professores de Língua Inglesa tem sido desafiadora. Nesse contexto, investiguei como se configuram a mobilização das Capacidades de Linguagem (CL) e dos Saberes e das Capacidades Docentes (CD) quando mediadas por elementos que constituem o Sistema de Atividade Docente. Para isso, pautei-me no Interacionismo Sociodiscursivo (ISD) e na Teoria Histórico-Cultural. Utilizei o Experimento Didático-Formativo enquanto metodologia de pesquisa, tendo as $\mathrm{CL}$, as $\mathrm{CD}$ e os tipos de correção como critérios para análise dos Planos de Ensino, das Sequências de Formação e Didáticas - produzidas e implementadas, das produçôes escritas, das transcriçôes e dos diários de aulas. Os resultados permitem dizer que o ensino sistematicamente organizado constitui-se como grande mediador para o desenvolvimento das CL e potencializam a mobilização das CD.

PALAVRAS-CHAVE: Formação Inicial de Professores de Língua Inglesa. Sequências de Formação. Saberes e Capacidades Docentes.

\section{INTRODUÇÃO}

O contexto de formação inicial de professores de Língua Inglesa (LI) tem sido foco de interesse de pesquisadores da Linguística Aplicada, o que tem exigido um repensar constante sobre a forma de ensinar e de aprender de modo a refletir a relação entre teoria e prática. Por essas razóes, a meu ver, o processo de formaçáo de professores de línguas deve atentar-se à articulação dos Saberes a Ensinar e para Ensinar, procurando orientar-se para um ensino de línguas enquanto prática social. Amparada por esta concepção, pautei-me no Interacionismo Sociodiscursivo - ISD (BRONCKART, 2007) e em conceitos advindos da Teoria Histórico-Cultural (VIGOTSKI, 2009) para a efetivação

\section{Linguagęm Foco \\ Revista do Programa de Pós-Graduação em Linguística Aplicada da UECE}

Universidade Estadual do Paraná, campus de Campo Mourão, Letras Português/Inglês, e-mail:mikelante@ gmail.com

Universidade Estadual de Londrina Programa de Pós-graduação em Estudos da Linguagem, e-mail: Programa de Pós-graduação em Estudos da Linguagem
Distribuído sob

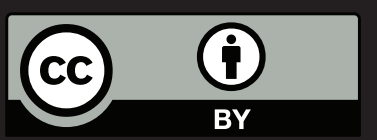


desta pesquisa.

\section{METODOLOGIA}

Apoiada em resultados de pesquisas anteriores (BASSO, 2001; SILVA, 2015), que apontaram para a necessidade de uma proposta investigativa, de cunho qualitativo, que pudesse vislumbrar uma reestruturação nos programas de ensino das disciplinas de LI, bem como no material didático utilizado do contexto investigado, realizei a implementação de Sequências de Formação (SF), nos anos de 2013 e 2014. Tal investigação objetivou confirmar ou refutar a tese por mim defendida de que o ensino de LI com base em gêneros, organizado em SF, pode contribuir tanto para o desenvolvimento das CL quanto para potencializar a mobilização das CD, ao articular os Saberes a Ensinar e para Ensinar (STUTZ, 2012), essenciais em um curso de formação inicial.

Para tanto, como metodologia de pesquisa, optei pelo Experimento Didático-Formativo (DAVYDOV, 1988), que, advindo da Educação, centra-se na aula, considerando o processo real das relaçôes entre o ensino e a aprendizagem e mostra-se como uma alternativa para as pesquisas. Assim, conforme ressignificação de Aquino (2014), inicialmente, realizei a revisão da literatura e o diagnóstico da realidade a ser estudada. Ao proceder o estudo do estado da arte, identifiquei uma lacuna de investigaçóes que discute o processo de ensino e aprendizagem de LI no curso de Letras. Efetuei, também, uma pesquisa documental dos Planos de Ensino das disciplinas de LI II e LI III, que orientaram a organização das SF implementadas, compostas pelos Textos Teórico-Metodológicos; Sequências Didáticas e Atividades Complementares

O contexto desta investigação foi um curso de Letras Português/Inglês - licenciatura dupla, ofertado por uma universidade pública do Estado do Paraná, em um dos seus campi. Grande parte dos futuros professores vem de outros municípios da região, sendo, em sua maioria, oriundos da Educação Básica Pública, com nível iniciante básico de LI. Os dados obtidos originaram de uma turma de professores em formação inicial (PFI), participantes das disciplinas de LI II e LI III

Das cinco SF implementadas, selecionei a SF4 como corpus principal da pesquisa. A escolha se deu por várias razóes, dentre as quais: i. a SF4 foi implementada em um período que não era inicial e nem final, podendo indicar resultado do processo; ii. a SD4 foi produzida por mim, professora-formadora, durante minha participação no grupo de professores que produziu material didático pela abordagem dos gêneros; iii. a SD4, em relação às demais Sequências Didáticas implementadas, foi a que manteve a proposta de produçáo e circulação do texto, conforme constava no Quadro-Sumário e no material.

A coleta e geração de dados ocorreram por meio dos seguintes instrumentos: a. Planos de Ensino; b. SF: b.1 SD e análise de suas consignas; b.2. Sequência de Ensino da SD4; b.3. Transcrição das aulas da SD4; b.4. Produções escritas do gênero Comentário e também aquelas comprobatórias das atividades de leitura de formação; b.5 Diários de Aula de uma PFI.

1 Do grupo maior foram selecionados quatro participantes que atendessem a proposição dos seguintes critérios: i. dois participantes do gênero masculino e duas participantes do gênero feminino, primando pela equidade de gênero; ii. dois participantes que estudassem a LI além do curso de Letras por mais de dois anos; iii. dois participantes que não estudassem a LI além do curso de Letras ou com menos de dois anos.

Revista Linguagem em Foco

Fortaleza, CE

v. 11 n. 2

ISSN 2674-8266 


\section{RESULTADOS E DISCUSSÃO}

Os resultados relacionados às articulaçóes existentes entre alguns dos itens que compóem os Planos de Ensino das disciplinas de LI II e LI III, a saber: ementas, objetivos, programas e as SF derivam da análise comparativa entre esses tópicos do documento e as SF. No que tange aos Saberes a Ensinar, os documentos apontam para um ensino com base em gêneros, tendo como objetivo o desenvolvimento das CL e o desenvolvimento de aspectos fonéticos e fonológicos da Língua Inglesa.

Nesse sentido, nos diferentes módulos das SD1 e SD4 foram identificadas atividades com potencial para mobilização das: i. Capacidades de Significação e de Ação, que se voltam para o contexto de produção (lugar social, momento da produção, emissor, receptor, objetivo); ii. Capacidades Discursivas e Multissemióticas, que se referem à organização do texto e do conteúdo temático, considerando uma determinada situação de interação e as possíveis relações de sentido que emergem do que é composto por linguagem verbal, não verbal e audiovisual; iii. atividades voltadas para aspectos léxico-gramaticais e algumas classes gramaticais presentes no texto, tais como verbos - modo e tempo; oraçóes declarativas; pronomes; adjetivos e marcas linguísticas inerentes ao gênero. É possível apontar uma articulação entre as Atividades Complementares com vistas ao desenvolvimento de aspectos fonéticos e fonológicos da Língua Inglesa e os Planos de Ensino de LI II e LI III, pois, aquelas, centraram-se nas vogais, semivogais e consoantes, tendo como ponto de partida as dificuldades apresentadas nas produçóes orais dos estudantes e, como instrumentos de mediação, atividades extraídas de sites da internet.

Em relação à formação teórico-metodológica, conhecimento constitutivo dos Saberes para Ensinar, as ementas pediam por textos que focassem no desenvolvimento do futuro do profissional prevendo leitura, discussão e reflexão sobre o professor em formação, em serviço e sobre o processo de ensino e aprendizagem de LI, envolvendo a leitura de dois textos por bimestre, sendo um artigo científico em português e um em inglês, com produção de um texto de compreensão por meio de Diários de Leitura, Resumos e Resenhas.

Para além do já tratado, os resultados apontaram para uma ruptura entre as ementas e os programas do Plano de Ensino de LI II e LI III, pois a LI III apresentava poucos indicadores de continuidade do trabalho desenvolvido anteriormente, não deixando entrever a apropriação dos Saberes a Ensinar e para Ensinar. Sua organização apresentava-se de forma distinta e os conteúdos elencados fundavam-se em uma perspectiva gramatical, corroborando os resultados de pesquisas anteriores (BASSO, 2001; SILVA, 2015).

O descompasso entre as ementas e os programas mostra a dificuldade de se efetivar o que é esperado do sistema de atividade do professor, por requerer um engajamento e uma articulação coletiva, demandando a constituição de um coletivo guiado por um sentido comum, intentando a promoção de uma formação sólida tanto no que diz respeito aos Saberes a Ensinar quanto aos Saberes para Ensinar.

Ao analisar, se e em que medida, as CL e as CD podem ser potencialmente mobilizadas nas Sequências de Formação, em especial, nas atividades escritas sobre os textos de formação e nas consignas das Sequências Didáticas, realizei uma descrição comentada dos elementos que compóem as cinco SF implementadas: SD, Atividades Complementares e Textos Teórico-Metodológicos. 
Tendo como base a macroestrura das SD, examinei cada uma das consignas que compóem as cinco SD, com base nos critérios propostos por Cristovão, et al. (2010) Cristovão e Stutz (2011) e Lenharo (2016). Destaco a articulação das Capacidades de Significação, Capacidades de Ação, Capacidades Discursivas, Capacidades Linguístico-Discursivas e Capacidades Multissemióticas, a depender do gênero central. Essa articulação oportunizou aos PFI a mobilização de seus conhecimentos prévios, relacionados a aspectos sócio-históricos e culturais, permitindo ao grupo reconhecer o contexto de produção, estabelecer relação com o contexto de recepção, atentando-se ao destinatário, à organização do conteúdo em cada um dos fragmentos e à função social do gênero, por meio dos recursos linguístico-discursivos e léxicogramaticais.

Quanto aos Saberes para Ensinar, as análises revelaram uma preponderância na mobilização das CD referentes a/ao: i. domínio dos métodos e técnicas pedagógicas que permitam a transposição dos conhecimentos científicos para os diferentes níveis de ensino - transposição didática; ii. domínio de referenciais teóricos contemporâneos educacionais e de formação para a compreensão e proposição de ações didático-pedagógicas; iii. desenvolvimento da criticidade e da criatividade por meio da linguagem; iv. realização da reflexividade tendo em conta os conhecimentos científicos e a vivência da realidade social e cultural; v. processo de multiletramentos; vi. práticas pedagógicas em consonância com as mudanças educacionais e sociais; vi. contexto e ao papel do professor na formação dos estudantes enquanto sujeitos sociais.

Em termos de formação para os Saberes a Ensinar, foram identificadas, entre outras, a possibilidade de mobilização das CD relacionadas a/ao: i. conhecimentos específicos de: i. aspectos fonológicos, morfossintáticos e léxico-gramaticais da língua inglesa, aspectos pragmático-discursivos da língua inglesa, aspectos multimodais; ii. uso da língua inglesa, nas suas manifestaçóes oral e escrita, em termos de recepção e produção de textos, considerando as relaçôes entre cultura e linguagem e os diferentes contextos sóciohistórico-culturais e diversidade linguística do inglês e seus aspectos geopolíticos.

Com o intuito de avaliar possíveis contribuições das etapas de escrita, correção, revisão e reescrita para o desenvolvimento das CL, resultantes do processo interacional entre os sujeitos envolvidos - professoraformadora e PFI, analisei as diferentes versões dos Comentários produzidos, durante a implementação da SD4, e os tipos de correção utilizados.

Os resultados indicaram correçôes do tipo interativo ou interativo-misto, resolutivo de supressão, indicativo, textual-interativa-apontamento e da textual-interativa-questionamento. Esses tipos de correção, se associados às CL, demonstraram que os PFI apresentaram dificuldades em relação a elas, apontando para a relevância de novas proposiçôes de atividades voltadas para mecanismos ainda não dominados por eles, que assumiram um papel responsivo, na reescrita da segunda versão e da Produção Final, com base nos textos interativos da professora-formadora. Essa prática demonstrou potencializar a mobilização das Capacidades de Significação, de Ação, Discursivas e Linguístico-Discursivas, pois a segunda versão apresentou alteraçóes no conteúdo e na forma de escrita, reduzindo as fragilidades identificadas na Produção Inicial, exceto o de uma das participantes. Tal prática de correção permite aos estudantes refletir sobre seu texto (Ruiz, 2013), contribuindo para o processo de revisão e reescrita, bem como para o desenvolvimento das CL, por meio da produção escrita, como defendido por Dolz, Gagnon

\begin{tabular}{c|c|c|c}
\hline Revista Linguagem em Foco & Fortaleza, CE & v. 11 n. 2 & ISSN 2674-8266 \\
\hline
\end{tabular}


e Decândio (2010).

$\mathrm{Na}$ esteira da compreensão de que os tipos de correção assumem a função de mediadores, os dados revelam um trabalho capaz de instigar os PFI a buscar possíveis soluçóes para as suas necessidades de aprendizagem, a fim de que possa haver avanços tanto em relação aos conteúdos a serem aprendidos quanto na tomada de consciência sobre o que deve ser o ato de ensino, envolvendo ambos os Saberes para Ensinar e a Ensinar.

\section{CONSIDERAÇÓES FINAIS}

Em relação às contribuições de ordem teórico-metodológica, destaco a utilização do Experimento Didático-Formativo como metodologia de pesquisa por sua organização permitir ao pesquisador contemplar, simultaneamente, o processo de ensino e o de aprendizagem. No que tange aos aspectos de ordem prática, os resultados obtidos permitem confirmar a importância da capacidade e autonomia do professor-formador para fazer adequaçôes ao material didático utilizado, atendendo, assim, às necessidades de seu contexto, no caso desta pesquisa, a formação docente inicial em um curso de Letras, nas disciplinas de LI II e LI III, por meio da implementação das SF.

As Sequências de Formaçáo, de Ensino e Didática, somadas a outros recursos didáticos empregados, provaram ser elementos mediadores fundamentais para o desenvolvimento das CL e dos Saberes e CD, necessárias a um futuro professor de Língua Inglesa. Desta feita, concluo que a aprendizagem resultante de um ensino com base em gêneros, por meio da SD, não é notável a curto prazo; que a produção de atividades orais, como Atividades Complementares, oportunizou aos PFI simular a inserção em uma situação de comunicação real para expressarem sua compreensão do assunto, a fluência, o domínio dos conteúdos gramaticais, entre outros, considerando-se as condições de produção e outros fatores centrados no texto e a interação entre seus interlocutores.

Ressalto que o processo interacional, nas etapas de escrita, correção, revisão e reescrita, teve como base o diálogo estabelecido entre a proposta de escrita como prática social, com foco na LI, sob a perspectiva do ISD e os tipos de correção propostos por estudiosos da língua materna. Esse diálogo oportunizou uma ATIVIDADE em que ambos, professora-formadora e PFI, puderam avaliar os resultados obtidos, por meio dos quais o tipo de correção utilizado potencializa a mobilização de uma ou mais CL, atendendo também às necessidades de conhecimentos transversais aos gêneros.

Enfim, o Sistema de Atividade envolvendo a formação docente inicial teve como MOTIVO investigar se o ensino e a aprendizagem com base em gêneros, cuja ATIVIDADE centrava-se na apropriação de Saberes a Ensinar e para Ensinar, por meio de AÇÓES pautadas em Sequências de Formação, de Ensino e Didáticas, guiadas por OBJETIVOS CONSCIENTES com vistas à mobilização das CL e das CD, demandaram várias OPERAÇÓES para que a proposta de pesquisa pudesse ser concretizada. Diante do apresentado, espero que os resultados desta pesquisa possam contribuir para avanços em estudos posteriores. 


\section{REFERÊNCIAS}

AQUINO, O. F. O Experimento Didático-Formativo: contribuiçôes para a pesquisa em didática desenvolvimental. In: Encontro nacional de didática e prática de ensino. Fortaleza: Eduece, 2015.

BASSO, E. A. A construção social das competências necessárias ao professor de língua estrangeira: entre o real e o ideal - Um curso de Letras em estudo. Tese (Doutorado em Lingüística Aplicada) v. 1. - Instituto de Estudos da Linguagem, UNICAMP, Campinas, 2001.

BRONCKART, J-P. Atividade de linguagem, textos e discursos: Por um interacionismo sócio-discursivo. Trad. Anna Rachel Machado e Péricles Cunha. 2. ed. São Paulo: EDUC, 1999/2007.

CRISTOVÃO, V. L. L.; et al. Uma proposta de planejamento de ensino de língua inglesa em torno de gêneros textuais. Letras (UFSM), v. 20, p. 191-215, 2010.

; STUTZ, L. Sequências Didáticas: semelhanças e especificidades no conteúdo francófono como L1 e no contexto brasileiro como LE. In: Szundy, P.T.C.; Araújo, J. C.; Nicolaides, C. S; Silva, R. A. (orgs.). Linguística aplicada e sociedade: ensino e aprendizagem de línguas no contexto brasileiro. Campinas: Pontes Editores, 2011, v1, p.17-40.

DAVYDOV, V. V. Problems of developmental teaching. The experience of theoretical and experimental psychological research. Soviet Education, New York, Aug. 1988a.

DOLZ, J.; GAGNON, R. Formação da didática do francês. No prelo,2017.

; GAGNON, R.; DECÂNDIO, F. Produçâo escrita e dificuldades de aprendizagem. Campinas, SP: Mercado de Letras, 2010. Produção e Divulgação do Conhecimento. Uberlândia, 2010. v. I. p. 1-11.

LENHARO, R. I. Participação Social por Meio da Música e da Aprendizagem de Lingua Inglesa em um Contexto de Vulnerabilidade Social. 2016. Dissertação (Programa de Pós-Graduação em Estudos da Linguagem) - Universidade Estadual de Londrina. Paraná, 2016.

LEONT'EV, A. N. Activity, Conciousness, and Personality, Englewood Cliffs, Prentice Hall, 1978.

MINAYO, M. C. S. Pesquisa Social: teoria, método e criatividade. São Paulo: Vozes, 2009.

RUIZ, E. D. Como corrigir redaçóes na escola: uma proposta textual-interativa. 1.ed. 2a reimp. São Paulo: Contexto, 2013.

SILVA, A. A. P. O trabalho do professor formador de língua inglesa e a natureza de aprendizagem na formação em pré-serviço. 2015. 298 f. Tese (Doutorado em Estudos da Linguagem) - Universidade Estadual de Londrina, Londrina, 2015.

STUTZ, L. Sequências Didáticas, socialização de diários e autoconfrontação: instrumentos para a formação inicial de professores de inglês. 2012, 383 f. Tese (Doutorado em Estudos da Linguagem) - Universidade Estadual de Londrina, 2012.

VIGOTSKI, L.S. A construção do pensamento e da linguagem. 2a ed. São Paulo: Martins Fontes, 2009.

\begin{tabular}{c|c|c|c}
\hline Revista Linguagem em Foco & Fortaleza, CE & v. 11 n. 2 & ISSN 2674-8266 \\
\hline
\end{tabular}

